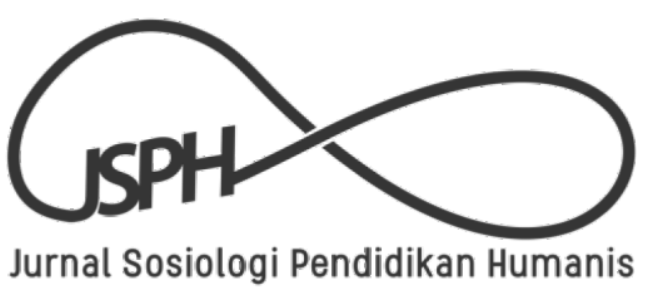

\title{
KEKERASAN SIMBOLIK MEDIA MASSA \\ (KEKERASAN SIMBOLIK DALAM PEMBERITAAN KASUS PEREDARAN VIDEO ASUSILA DI MEDIA MASSA ON LINE: KAJIAN SOSIOLOGI KOMUNIKASI)
}

\author{
Farid Pribadi \\ Program Studi Sosiologi Universitas Negeri Surabaya \\ Email:faridpribadi@gmail.com
}

\begin{abstract}
Abstrak
Media massa dalam memberitakan kasus privasi salah satunya kasus penyebaran video asusila remaja masih terjebak pada logika pasar. Untuk menarik minat pembaca, awak media membangun gaya penulisan yang terkesan sensasional dan vulgar. Akibatnya, entah disadari atau tidak dibalik pengungkapan fakta yang rinci tersebut telah melakukan kekerasan simbolik (symbolic violence) berupa penggunaan bahasa eufemisme yang berdampak pada hadirnya praktik pelabelan negatif atau stereotipe sehingga memicu potensi traumatik berkepanjangan kepada pelaku bahkan keluarga pelaku.
\end{abstract}

Kata Kunci : media massa, kekerasan simbolik, stereotipe

\author{
MASS MEDIASYMBOLIC VIOLENCE \\ (SYMBOLIC VIOLENCE THROUGHADOLESCENT IMMORAL VIDEO ON \\ ONLINE MASS MEDIA: SOCIOLOGY OF COMMUNICATIONANALYSIS)
}

\begin{abstract}
Reported on privacy one, in case spreading adolescent immoral video, mass media already have trapped into marketing logical. Mass media have been set up sensational and vulgar rhetorics for attracting readers. Whether realize or not by readers, facts are contains symbolic violence such as eufimism diction that impacted into stereotype and caused physical traumatic to the actor and their family
\end{abstract}

Keyword : mass media, symbolic violence, stereotipe 


\section{LATAR BELAKANG}

Urgensi penelitian ini berangkat dari kegelisahan ketika media massa memberitakan kasus peredaran video asusila justru dalam gaya penulisannya terkesan ikut berperan memperluas konten-konten pornografi berupa kata-kata atau kalimat berbau seks apalagi disertai potonganpotongan gambar hubungan badan pelakumeski dikaburkan. Gaya pengungkapan semacam ini justru dapat menstimulasi masyarakat termasuk kalangan pelajar dan remaja mengunduhnya di internet.

Selanjutnya peliputan kasus kejahatan seksual yang melibatkan anak-anak dan remaja identitasnya lazimnya lebih dilindungi oleh kode etik jurnalistik justru diungkap bak selebritas. Meski tidak memuat nama lengkap, melainkan hanya inisial namun identitas kedua remaja itu masih mungkin dilacak oleh publik sebab nama sekolah mereka disebutkan dengan jelas. Gaya peliputan semacam inilah media massa terjebak pada praktik kekerasan simbolik (symbolic violence). Kekerasan simbolik adalah makna, logika, dan keyakinan yang mengandung bias tetapi secara halus dan samar dipaksakan kepada pihak lain sebagai sesuatu yang benar (Fashri, 2007).

Kekerasan simbolik terjadi melalui media bahasa yang nantinya akan memengaruhi cara berpikir, cara kerja, dan cara bertindak. Sebagai praktik sosial, bahasa merupakan hasil interaksi antara struktur sosial dengan habitus linguistik. Jagat sosial bagi Bourdieu merupaka arena pertarungan, arena adu kekuatan. Sebagai arena pertarungan, pemenang akan ditentukan oleh kepemilikan terhadap modal kapital. Kelas dominan yang dominan terhadap kepemilikan modal kapital akan memenangkan pertarungan. Modal kapital ini dapat berupa ekonomi, budaya, sosial, dan simbolik. (Rusdiarti, 2003:34).

Oleh karena itu, dalam praktik kekerasan simbolik tidak ada korban luka fisik secara langsung. Dengan kata lain, selain dalam kondisi masih bersedih pelaku dan keluarga pelaku tanpa sadar 'dipaksa' harus menanggung malu akibat peliputan yang massif dan sensasional tersebut yang berpotensi memunculkan pelabelan negatif, stereotipe bahkan stigmasi (cap buruk, cemoohan, gunjingan) dari lingkungan luar yang berpeluang menimbulkan traumatis berkepanjangan bahkan dikucilkan dari lingkungan sekitar.

Berdasarkan ilustrasi di atas, maka tujuan penelitian ini hadir sebagai upaya untuk memahami bagaimana bentuk-bentuk kekerasan simbolik dalam isi pemberitaan kasus video porno pelajar di media massa online?

$1 \quad$ Fakta tentang bagaimana media massa juga turut menyumbang penyebaran konten porno baik tayangan gambar dan teks yang berbau seks atau porno seperti diatas pernah diungkap lembaga Kajian Informasi, Pendidikan dan Penerbitan Sumatra (KIPPAS). Riset yang dilakukan analis media KIPPAS menemukan banyak penggunaan diksi yang bersifat konotatif ketika jurnalis mengkonstruksi peristiwa perkosaan. Dari 62 item berita yang dijadikan sampel sepanjang periode waktu riset, ditemukan ada sebanyak 49 item berita yang mengggunakan ungkapanungkapan eufemisme dan metafora. Eufemisme muncul pada 31 item berita atau $(50 \%)$, dan metafora muncul dalam 16 item berita atau $(25,81 \%)$. Jenis kekerasan simbolik lainnya adalah stigmatisasi, disfemisme dan hiperbola. Baca https://kippas.wordpress.com/2007/06/04/k etika-jurnalisme-kehilangan-empati/ diakses Selasa 7 Juni 2016 pukul 13.00 WIB 


\section{METODE PENELITIAN}

Penelitian ini mengadaptasi pendekatan kualitatif dengan menggunakan metode semiotika sosial yang dikemukakan M.A.K Halliday. Halliday berpendapat bahwa teks adalah suatu pilihan semantis (semantic choice) dalam konteks sosial, suatu cara pengungkapan makna lewat bahasa lisan atau tulis. Kerangka kerja semiotika sosial M.A.K Halliday (1978) terdiri dari tiga konsep: Medan wacana merujuk pada tindakan sosial yang sedang terjadi atau dibicarakan, aktivitas di mana para pelaku terlibat di dalamnya, serta praktik-praktik yang terlibat di dalam teks. Pelibat Wacana mengidentifikasi pihak-pihak - pembicara dan sasaran - yang terlibat dalam pembicaraan, serta kedudukan dan hubungan di antara mereka. Sedangkan mode wacana, merujuk pada pilihan bahasa masing-masing media, termasuk apakah gaya bahasa yang digunakan bersifat eksplanatif, deskriptif, persuasif, metaforis, hiperbolis, dan lain-lain, serta bagaimana pengaruhnya.

Penelitian ini berupaya menggambarkan kekerasan simbolik yang dilakukan media massa online melalui praktik penggunaan kata-kata maupun gambar pada liputan kasus video porno pelajar di Bogor Jawa Barat sekitar bulan Mei tahun 2016. Diantaranya www.pojoksatu.com (alamat berita online http: //sulsel. pojoksatu. id/read/2016/05/21/video-mesum-siswasmp-beredar-kepsek-kaget/) dan www.beritasatu.com (alamat berita online http://www.beritasatu.com/megapolitan/366 045-polisi-selidiki-penyebaran-videoporno-pelajar-smp.html). Pertimbangan memilih media massa online dibandingkan "media konvensional" (cetak/elektronik) adalah kemudahan akses untuk mendapatkan berita dan kecepatan penayangan hasil liputan berita.

Metode pengumpulan data dalam penelitian ini menggunakan metode simak. Metode simak merupakan cara pengumpulan data dengan menyimak penggunaan bahasa. Teknik lanjutan yang digunakan dalam metode simak ini adalah Teknik Simak Bebas Libat Cakap (SBLC) dan teknik catat (Sudaryanto, 1993). Teknik Simak Bebas Libat Cakap (SBLC), dalam hal ini peneliti bekerja sebagai pemerhati data peristiwa kebahasaan yang berada diluar dirinya.

Kronologi pencarian sumber data di media massa online akan diperoleh melalui beberapa tahapan sebagai berikut: pertama, melakukan observasi berupa membaca seluruh berita headline tentang kasus video porno oleh pelajar. Kedua, data berita headline terkait fokus penelitian, kemudian didokumentasi kemudian disusun rapi dan di analisis dan diinterpretasikan oleh peneliti berdasarkan formulasi teori dan metode yang ada. Ketiga, hasil analisis kemudian ditarik kesimpulan.

\section{PEMBAHASAN}

Eriyanto (2002) menyebutkan bahwa pekerjaan media pada hakekatnya adalah mengkonstruksi realitas, dan isi media adalah hasil karya para pekerja media mengkonstruksi berbagai realitas yang dipilihnya. disebut konstruksi sosial (social construction) menurut sosiolog Peter L. Berger dan Thomas Luckmann (1966) terbentuk melalui tiga tahapan yakni eksternalisasi, objektifikasi, dan interna-lisasi. 
Eksternalisasi mengandung arti usaha ekspresi individu kedalam dunia sosial, baik kegiatan mental atau fisik. Kegiatan atau momen ini bersifat kodrati. Individu menggunakan sarana bahasa dan tindakan berusaha untuk beradaptasi dengan lingkungannya. Manusia menggunakan bahasa untuk melakukan adaptasi dengan dunia sosikulturalnya dan selanjutnya tindakannya tersebut juga disesuaikan dengan dunia sosio-kulturalnya. Sehingga pada momen ini, terkadang dijumpai ada individu yang mampu beradaptasi dan sebaliknya. Penerimaan dan penolakan tergantung dari apakah individu tersebut mampu atau tidak beradaptasi dengan dunia sosio-kultural tersebut.

Objektivikasi merupakan proses dimana individu berusaha untuk berinteraksi kembali dengan dunia sosio-kulturalnya untuk membangun kesadaran yang selanjutnya diwujudkan kedalam bentuk tindakan. Didalam momen ini, nilai-nilai yang menjadi pedoman didalam melakukan interpretasi terhadap tindakan telah menjadi bagian yang tak terpisahkan sehingga apa yang disadari sebagai kebenaran adalah apa yang dilakukan.

Internalisasi merupakan momen identifikasi diri dalam dunia sosio-kultural. Kegiatan ini berupa penyerapan kembali dunia objektif ke dalam kesadaran subjektif yang pada akhirnya individu dipengaruhi oleh struktur sosial yang mengitarinya.

Berdasarkan ulasan teori kostruksi sosial yang dikemukakan Berger, jika dikaitkan dengan realitas peliputan kasus berita kasus video porno pelajar di Kota Bogor Jawa Barat sekitar bulan Mei tahun 2016 yang disajikan www.pojoksatu.com dan www.beritasatu.com adalah realitas sosial yang dibangun para awak media melalui bangunan realitas simbolik. Problemnya realitas yang dibentuk media ini dianggap sebagai kebenaran oleh audiens.

\section{Menyalakan Syahwat Melalui Berita}

Mengadaptasi kerangka kerja semiotika sosial M.A.K Halliday (1978) dapat dianalisis dengan diawali memahami medan wacana. Medan wacana merujuk pada tindakan sosial yang sedang terjadi atau dibicarakan, aktivitas di mana para pelaku terlibat di dalamnya, serta praktik-praktik yang terlibat di dalam teks. Kedua media massa online tersebut sama-sama berusaha mengungkap terkait siapa sesungguhnya pelaku pemeran dan penyebar video asusila.

Pada portal www.beritasatu.com berusaha menggali siapa pelaku video porno tersebut dengan menggunakan dua narasumber dari pihak kepolisian dankepala sekolah tempat terduga pemeran video porno pelajar mengenyam pendidikan. Hasil wawancara dari narasumber Kapolres Kota Bogor AKBP Andi Herindra mengungkapkan akan menindaklanjuti kasus video asusila inidengan menugaskan satuan reserse kriminal (satreskrim) untuk mengungkap siapa pelaku pemeran dan penyebar video asusila tersebut. Menggunakan narasumber dari pihak kepolisian adalah strategi wartawan ini untuk menggiring kesadaran pembaca bahwa kasus video asusila ini masuk kasus kriminal. Disamping itu, menempatkan pernyataan dari pihak kepolisian diparagraf awal mengartikan bahwa kasus ini diilustrasikan lebih mengandalkan keterangan perspektif pihak kepolisian, dan bukan dari perspektif pelaku pemeran maupun penyebar video asusila 
yang sebenarnya jauh lebih memahami peristiwa yang terjadi.

Wartawan yang bernama Ignatius Herjanjam ini juga menyuguhkan hasil penelusuran informasi seputar identitas pelaku adegan dan penyebar video asusila tersebut. Hasilnya terdapat nama berinisial PU adalah diduga pelaku perekaman sekaligus penyebar video asusila sedangkan pelaku pemeran video berinisial FS dan SR. Selain itu, informasi terkait motif pelaku menyebarkan juga diungkap yakni karena PU merasa sakit hati terhadap teguran pemilik kos disebabkan dicurigai kamar kos PU dijadikan tempat maksiat rekan-rekannya. Akibat tidak terima teguran tersebut PU sembunyi-sembunyi merekam ke dua pelaku pemeran adegan video asusila kemudian menyebarkan di akun sosial media facebook. Ignatius juga mendeskripsikan isi video berikut durasinya.

Ignatius menutup berita dengan ulasan pernyataan kepala sekolah SMPN 10 Kota Bogor Kusmana yang berisi bantahan tudingan bahwa PU dan SR adalah siswanya. Menurut Kusmana kedua siswa tersebut sudah dikeluarkan tahun lalu dan merasa kecewa terhadap pelaku yang menggunakan seragam saat memerankan adegan asusila tersebut. Sehingga, menurut Kusmana, ada dugaan upaya mencemarkan nama baik sekolah.

Sedangkan www.pojoksulsel. com hanya menggunakan narasumber kepala sekolah SMPN 10 Kota Bogor Kusmana dengan tujuan ingin mendalami siapa identitas sebenarnya pelaku adegan, penyebar video porno dan asal sekolah para pelaku. Keterkejutan Kusmana mendengar informasi dugaan siswanya tersangkut kasus video asusila. Mendengar informasi tersebut Kusmana langsung memanggil para wali kelas untuk mengecek nama siswa yang terkait. Hasilnya menurut Kusmana siswa berinisial FS dan SR sudah dikeluarkan tahun lalu dari sekolah. Kusmana juga menyesalkan pelaku adegan menggunakan seragam sekolah SMPN 10 Kota Bogor yang diduga ada indikasi upaya mencemarkan nama baik sekolah. Berita ini juga menampilkan cuplikan potongan isi video sebanyak tiga buah.

\section{Corong Aparat Dan Pejabat.}

Pelibat Wacana mengidentifikasi pihak-pihak pembicara dan sasaran yang terlibat dalam pembicaraan, serta kedudukan dan hubungan di antara mereka. kedua media massa ini menggantungkan narasumber dari sumber-sumber resmi yakni kepolisian dan kepala sekolah SMPN 10 Kota Bogor.

\section{Tabel 1 Medan Wacana pada Kedua Portal}

www.beritasatu.com -Penyelidikan pihak kepolisian Kota Bogor terkait penyebaran video porno yang diduga dilakukan PU (15) pelajar SMPN di Kota Bogor. -Hasil penelusuran wartawan terkait motif perekaman dan penyebaran video porno yang dilakukan PU (15)

-Deskripsi terkait isi dan durasi video porno.

-Hasil wawancara kepala sekolah SMPN 10 terkait kebenaran pelaku penyebar dan pemeran video porno adalah siswanya.

www.pojoksulsel.com -Hasil wawancara kepala sekolah SMPN 10 terkait kebenaran pelaku penyebar dan pemeran video porno adalah siswanya. 
Hampir tak ada suara dari pelaku pemeran atau penyebar atau warga sipil dilingungan pelaku, yang mungkin bisa memberikan informasi lebih tepat. Model pemberitaan semacam ini memperlihatkan mayoritas produksi berita masih berpusat di kalangan aparat dan pejabat sehingga terkesan media memberitakan dengan cara menggilir narasumber berita dari satu elit ke elit yang lain. Sehingga media disadari atau tidak lebih dari corong aparat dan pejabat.

Portal twww.beritasatu.com berusaha mengawali paragraf dengan menyuguhkan hasil wawancara dengan pihak kepolisian Kapolres Kota Bogor AKBP Andi Herindra seputar upaya sigap penelurusan pencarian siapa pelaku adegan, siapa pelaku penyebar video porno dan apa motifnya. Hasil wawacara pihak kepolisian yang diletakkan diawal paragraf ini adalah upaya memberikan pemahaman kepada pembaca bahwa kasus video porno yang diduga dilakukan oleh pelajar sudah terkategori tindak kejahatan yang meresahkan masyarakat khususnya Kota Bogor sehingga pelakunya harus ditindak.

Berikutnya adalah narasumber kepala sekolah SMPN 10 Kota Bogor Kusmana. Hasil wawancara kepala sekolah ini mendapatkan porsi dua pragraf diakhir berita berisi tentang bantahan keterlibatan siswanya terkait kasus dugaan pelaku adegan dan pelaku penyebaran video porno. Menurut Kusmana kedua pelaku adegan asusila sudah dikeluarkan tahun lalu.

Sementara www.pojoksulsel.com menampilkan narasumber utama yakni kepala sekolah kepala sekolah SMPN 10 Kota Bogor Kusmana. Keseluruhan paragraf berita berisikan hasil wawacara seputar konfirmasi kebenaran pelaku adegan video porno yang diduga diperankan siswa SMPN 10 Kota Bogor. Ilustrasi penulisan hasil wawancara diawali dengan pengungkapan reaksi terkejut Kusmana mendengar adanya informasi ada siswanya tersangkut masalah kasus video asusila. Kusmana kemudian langsung mengumpulkan seluruh wali murid untuk mencari siapa siswa yang mengupload video asusila dan pelaku adegan tersebut.

Setelah melakukan kordinasi dengan wali murid dan melakukan pengecekkan data siswa, Kusmana menyatakan bahwa siswa yang tersangkut masalah video asusila tersebut sudah dinyatakan keluar sejak tahun lalu. Namun demikian, Kusmana prihatin sekaligus kecewa terkait penggunaan seragam sekolah SMPN 10 Kota Bogor oleh pelaku adegan asusila tersebut. Kusmana menduga ada oknum yang berusaha menjatuhkan nama baik sekolah. Mengandalkan narasumber utama kepala sekolah dimungkinkan media massa online ini ingin mengungkapkan bahwa fenomena pemeran adegan video asusila masih saja ditemukan pelakunya adalah remaja kalangan pelajar.

\begin{tabular}{ll}
\hline \multicolumn{2}{c}{ Tabel 2. Pelibat Wacana } \\
\hline www.beritasatu.com & -Kepolisian Kota Bogor \\
& -Kepala Sekolah SMPN \\
& 10 Kota Bogor \\
\hline www.pojoksulsel.com & -Kepala Sekolah SMPN \\
& 10 Kota Bogor \\
\hline
\end{tabular}

\section{Mengungkap atukah Menyudutkan}

Mode wacana, merujuk pada pilihan bahasa masing-masing media, termasuk apakah gaya bahasa yang digunakan bersifat eksplanatif, deskriptif, persuasif, metaforis, hiperbolis, dan lain-lain, serta bagaimana 
pengaruhnya. Kedua media massa online baik www.beritasatu.com dan www.pojoksulsel.com sama-sama berupaya menuliskan kasus video asusila dengan menggunakan gaya pengungkapan deskrpitif yakni dengan menggunakan pilhan kata-kata yang berbeda keduanya berusaha ingin menuliskan bagaimana peristiwa tersebut terjadi dan siapa saja yang terlibat dalam kasus tersebut.

Misalnya www.beritasatu.com menggunakan judul Polisi Selidiki Penyebaran Video Porno Pelajar SMP. Judul ini digunakan untuk menggiring pembaca bahwa kasus ini adalah kasus yang meresahkan dan sudah masuk kedalam ranah hukum sehingga harus didalami pihak kepolisian. Penggunaan kata Polisi Selidiki... adalah strategi untuk membatasi opini pembaca terhadap isi berita yang disampaikan sumber resmi yakni pihak kepolisian. Informasi dari pihak kepolisian dinilai adalah sumber yang valid dan dapat dipertanggungjawabkan secara hukum.

Berikutnya penggunaan kata dan peletakkan kata porno baik didalam judul dan didalam beberapa paragraf yang berisikan pernyataan dari pihak kepolisian memiliki maksud tersendiri. Kata porno dalam kamus besar bahas Indonesia versi online (www.kbbi.web.id) memiliki arti kependekan pornografi. Dengan kata lain, kata porno dapat bermakna sebagai gambar yang bermuatan cabul.

\section{Polisi Selidiki Penyebaran Video Porno Pelajar SMP \\ Bogor - Kepolisian Resor (Polres) Kota Bogor hingga Sabtu (21/5) ini terus menyelidiki kasus penyebaran video porno yang dilakukan PU (15) pelajar SMPN di Kota Bogor.}

Berbeda halnya dengan penggunaan kata mesum yang diletakkan diantara beberapa kalimat hasil penelusuran informasi yang dilakukan Igantius seputar kronologi kasus tersebut. Selain itu, kata mesum juga tersebar diantara pernyataan kepala sekolah SMPN 10 Kota Bogor.

...dia mengunggah video mesum rekannya SR dan FS. Kekesalan PU memuncak saat mengetahui kamar kosnya dijadikan ajang berbuat mesum FS dan SR.

Dalam rekaman yang diunggah $P U$, tampak adegan mesum ...

untuk mengunggah video mesum itu untuk membuktikan

Kusmana juga menyayangkan tindakan FS yang menggunakan seragam SMPN 10 dalam adegan mesum itu.

Kata mesum, menurut www.kbbi.web.id berarti kotor; cemar (tentang pakaian, badan, dan sebagainya); tidak senonoh; tidak patut; keji sekali (tentang perbuatan, kelakuan, dan sebagainya); cabul.

Penggunaan kata 'porno' dan 'mesum' adalah strategi gaya bahasa eufemisme yakni gaya pengungkapan yang lebih halus sebagai pengganti ungkapan yang dirasa kasar namun dari kandungan maknanya tidak memiliki perbedaan. Dengan demikian, ada strategi penempatan kata yang lebih halus untuk pihak kepolisian dan kata yang kasar untuk pelaku dan kepala sekolah. Strategi penempatan kata semacam ini menggiring kesadaran pembaca perihal pelaku telah berbuat tidak senonoh, tidak patut, keji dan cabul. Disamping itu, kepala sekolah diarahkan sebagai pihak yang telah lalai dalam mendidik siswanya tersebut.

Berikutnya, www.beritasatu.com juga menggunakan kata hiperbolis dengan menuliskan ... kasus tersebut telah membuat gaduh Kota Bogor karena telah diunggah di 
sosial media. Kalimat ini digunakan untuk menggambarkan masyarakat Kota Bogor merasa resah akibat kasus ini, meski kenyataannya belum tentu demikian.

Ilustrasi tentang isi video juga diungkap media massa online.

Dalam rekaman yang diunggah PU, tampak adegan mesum berdurasi 8 menit 59 detik yang memperlihatkan FS siswi yang mengenakan seragam SMPN 10 berhubungan intim dengan kekasihnya SR yang memakai kaos hitam. PU lalu merekam adegan tersebut secara sembunyi dari luar jendela kamar.

Gaya peliputan dengan menceritakan isi video mungkin tidak menyadari bahwa pemuatan potongan video seperti ini dapat melanggar kode etik jurnalistik dan hukum mengenai kehidupan pribadi atau privasi dan pornografi. Gaya peliputan bak selebritas yang identitasnya lazimnya lebih dilindungi oleh kode etik jurnalistik. Di dalam UndangUndang Perlindungan Anak Tahun 2002 pasal 13 ditegaskan bahwa anak berhak mendapat perlindungan dari perlakuan eksploitasi ekonomi dan seksual.

Portal www.pojoksusel.com mengawali pemberitaan menuliskan judul berita Video Mesum Siswa SMP Beredar, Kepsek Kaget. Penggunaan kata 'mesum' lebih dipilih media massa online ini dimungkinkan lebih menonjolkan sisi bahasa dan tampilan berita yang seksis dan bernlai ekonomis tinggi. Selanjutnya, penggunaan kalimat judul ...kepsek kaget adalah upaya wartawan mendeskripsikan bagaimana reaksi kepala sekolah SMPN 10 Kota Bogor Kusmana mendengar informasi bahwa ada dugaan siswanya terkait masalah kasus video asusila. Berikutnya, tiga potongan gambar video asusila yang diperankan dua remaja tanpa sensor dengan ukuran gambar yang cukup besar. Meski warna gambar tampak berwarna hitam putih namun pelaku pemeran remaja siswi tampak samarsamar terlihat menggunakan pakaian seragam sekolah. Gambar tersebut diberikan keterangan gambar bertuliskan Capture video mesum siswa SMP 10 Bogor. Penulisan keterangan gambar semacam itu seakan-akan wartawan sudah memastikan bahwa kedua siswa tersebut adalah siswa SMPN 10 Bogor.

Peletakkan judul kemudian suguhan gambar potongan video semacam itu adalah upaya menggiring pemahaman pembaca agar 'mengamini' bahwa orang dalam gambar cuplikan video tersebut adalah remaja siswa SMPN 10 Bogor. Efek peletakkan gambar dan judul semacam ini adalah upaya untuk membatasi munculnya opini dari pembaca seputar asal usul kebenaran para pelaku kasus video asusila tersebut.

Di awal paragraf berisi tentang keterkejutan Kusmana saat dikonfirmasi oleh sejumlah wartawan terkait dua siswanya yang tersangkut masalah video asusila yakni FS dan SR.

BOGOR - Kepala Sekolah (Kepsek) SMPN 10 Bogor Kusmana kaget saat dikonfirmasi terkait beredarnya video mesum dua siswanya di media sosial. Dua siswa pemeran video mesum itu yakni FS dan SR.

Gaya penulisan dan tata letak judul berita, penempatan potongan gambar yang disertai keterangan gambar serta susunan kalimat diparagraf awal berisi Dua siswa pemeran video mesum itu yakni FS dan SR seolah-olah siswa pemeran adegan asusila tersebut memang benar dan dipastikan berasal dari sekolah yang dipimpim Kusmana. Akibat gaya penulisan semacam 
ini dibeberapa isi paragraf berikutnya terkesan hanya berisikan tentang sikap penuh kepanikan dari seorang kepala sekolah dalam menghadapi persoalan tersebut. Sehingga langkah Kusmana mengumpulkan seluruh wali kelas dan wakil kepala sekolah untuk mencari tahu identitas kedua pemeran adegan asusila tersebut.

"Saya baru tahu ada kejadian ini, dan saya akan langsung kumpulkan para wakil untuk mencaritahu kebenaran ini, " ujarnya kepada Radar Bogor, Jumat (20/05/2016).

Setelah mengecek daftar siswanya, Kusmana mengatakan pemeran video mesum itu sudah tidak bersekolah lagi di SMPN 10 Bogor. Keduanya sudah dikeluarkan tahun lalu. Hanya, menurutnya, salah satu dari pemeran video sengaja menggunakan baju seragam sekolah SMPN 10 Bogor.

"Saya baru tahu ada kejadian ini, dan saya akan langsung kumpulkan para wakil untuk mencaritahu kebenaran ini," ujarnya kepada Radar Bogor, Jumat (20/05/2016).

Setelah mengecek daftar siswanya, Kusmana mengatakan pemeran video mesum itu sudah tidak berseko-lah lagi di SMPN 10 Bogor. Keduanya sudah dikeluarkan tahun lalu. Hanya, menurutnya, salah satu dari pemeran video sengaja mengguna-kan baju seragam sekolah SMPN 10 Bogor.

Ilustrasi teks berita urutan kelima dan keenam diatas yang berisikan seputar langkah-langkah yang diambil Kusmana tersebut justru mencitrakan sosok kepala sekolah yang reaksionis. Yakni pemimpin yang baru bekerja atau bertindak ketika sudah terjadi sesuatu yang merugikan. Akibatnya seseorang dalam bertindak cenderung disertai sikap emosi atau marah.
Sebelum ke urutan paragraf ke tujuh, wartawan www.pojoksulsel.com memasukkan judul berita yang isinya hampir menyerupai kasus peredaran video asusila pelajar di Bogor. Judul berita tersebut adalah $B A C A$ : GEGER! Video Mesum Siswa SMP. Hot Banget.. Judul berita sisipan ini adalah strategi wartawan agar pembaca dapat 'menikmati' sajian berita serupa dengan cara mengklik teks judul berita tersebut. Strategi penulisan judul danpeletakkan judul berita semacam inilah mengindkasikan bahwa berita seputar seks masih menjadi primadona media massa karena bernilai ekonomis tinggi.

Di paragraf berikutnya, dituliskan tentang masa kerja Kusmana yang masih baru dua bulan memimpin SMPN 10 Kota Bogor merasa tidak ada masalah dilingkungan sekolah. Sehingga Kusmana merasa 'kecolongan' atas peristiwa tersebut. akibat kecolongan atas munculnya peristiwa tersebut, Kusmana ditampilkan tampak sedang emosi dalam menyatakan konfirmasinya kepada wartawan. Hal ini ditandai dengan penggunaan kata tukas tandas Kusmana yang diletakkan diakhir kalimat. Kata tukas dan tandas yang ada didalam www.kbbi.web.id berarti mendakwa (menuduh) tanpa alasan yang cukup (asal menuduh saja). Sedangkan tandas habis semuanya; hilang sama sekali; habishabisan. Jika dua kata tersebut dirangkai dapat dimaknai bahwa Kusmana dalam mengeluarkan pendapatnya semata-mata untuk memperjuangkan nama baik sekolahnya meski pun dengan cara menuduh ada oknum yang ingin mencemarkan sekolah yang baru dipimpinnya selama dua bulan. 
Kusmana yang baru dua bulan memimpin SMPN 10 Kota Bogor mengaku, salama ini tidak ada hal-hal yang tidak wajar di sekolah yang dipimpinnya itu.

"Kok dia sudah dikeluarkan masih pakai seragam sekolah, maksudnya apa? Apa mau jelekin nama sekolah?" tukas tandas Kusmana.

\section{Sudah Jatuh Tertimpa Tangga.}

Berdasarkan dari hasil serangkaian tahapan analisis semitoika Halliday berupa medan wacana, pelibat wacana, dan mode wacana kedua media massa tersebut masih menempatkan realitas sosial berbau seks menjadi daya tarik untuk diungkap secara detail. Diantaranya pengungkapan inisial nama dan ciri-ciri pelaku penyebar dan pemeran video, penayangan potongan tayangan isi video dan deskripsi isi video, dan reaksi kepala sekolah. Gaya pengungkapan semacam ini bisa jadi karena mampu menarik minat baca para pembaca untuk kemudian dapat bernilai ekonomis tinggi.

Akan tetapi dibalik pencapaian target ekonomis yang tinggi justru gaya pengungkapan kasus semacam ini awak media massa justru telah terjebak ke dalam jurang 'pelestari pornografi' lewat karya pemberitaan yang cendurung vulgar, seksis, dan penuh sensaional. Kenyataan ini Bungin mengemukakan, pornografi dalam pemberi-taan disebabkan tingginya persaing-an media massa itu sendiri, sehingga berita atau gambar erotika digunakan sebagai daya tarik untuk meningkatkan daya saing (Bungin, 2001).

Bungin menambahkan, bahwa erotisme di media massa tidak saja berkaitan dengan eksploitasi, tetapi juga juga norma dan moral agama, serta masyarakat. Bungin bahkan mencurigai adanya pembenturan antara kepentingan media massa dengan norma, agama, dan pendidikan masyarakt luas. Akibatnya, media massa dianggap sebagai suatu bentuk patologi sosial oleh sejumlah kalangan.

Hal senada juga di kemukakan Yasraf Amir Pilliang bahwa pemberitaan dengan penggunaan tubuh perempuan di media massa merupakan masalah political economy of the body, yakni perempuan dijadikan komoditi untuk kepentingan ekonomi yang didasarkan pada konstruksi sosial dan ideologi tertentu (Yasraf Amir, 2000). Dengan kata lain, penggunaan tubuh perempuan di media sebagai salah satu ajang pornografi merupakan sesuatu yang dipolitisasi berdasarkan kepentingan pasar.

Yasraf menjelaskan elemen-elemen utama yang dapat menciptakan pelbagai tanda tubuh (body sign) yang dieksploitasi sebagai komoditi (commodity signs) di dalam pelbagai media kapitalistik, dalam rangka menimbulkan daya tarik media:

Pertama, tanda kecabulan (obscene signs). Kecabulan di dalam media tampak lewat tindak sensual atau simulasinya yang ditampilkan baik secara langsung atau tersamar memegang, mengelus, meraba, meremas, mendekap, memangku. Tindakan secara sosial mengganggu orang-orang yang melihat, dengan alasan tabu, larangan, etis, moral, norma, agama, dan sebagainya.

Kedua, overesposed sign, yaitu caracara mengeskpose tubuh dari organ-organ tubuh (paha, betis, payudara, kelamin) sebagai domain tontonan publik, denagn cara memasuki dan menjajah apa yang selama ini disebut sebagai domain private di dalam sebuah kebudayaan. 
Ketiga, tanda seksual (sexual sign), yaitu tanda-tanda yang mengarah pada tindakan hubungan seksual (Morris, 1977). Hubungan seksual baik secara tersamar (misalnya, dengan teknik blurring, raster, pengaburan gambar, ditutupi teks) atau secara eksplisit seringkali ditampilkan.

Berdasarkan ulasan di atas dapat di pahami bahwa upaya penonjolan pornografi telah menjadi bagian yang dianggap memiliki 'nilai jual' tinggi di pasaran. Oleh sebab itu, media massa bukan hanya sebagai alat menyalurkan pesan, tetapi juga adalah lembaga sosial dan lembaga bisnis (Anwar. 2003). Akhirnya, tubuh dan pornografi dalam konstruksi media massa selalu ambigu pada titik yang sama, yakni antara menampilkan sesuatu yang objektif ataukah eksploitatif.

Media massa mungkin tidak menyadari bahwa pemuatan potongan video atau pengungkapan detail pelaku remaja seperti ini dapat melanggar kode etik jurnalistik dan hukum mengenai kehidupan pribadi atau privasi dan pornografi. Padahal gaya pengungkapan yang terkesan vulgar dan eksploitatif tersebut media massa dapat melanggar Undang-Undang Perlindungan Anak Tahun 2002 pasal 13 tentang anak berhak mendapat perlindungan dari perlakuan eksploitasi ekonomi dan seksual. Dari segi hukum pemuatan foto remaja ini dapat melanggar Pasal 13 UU Perlindungan Anak, dari sisi kode etik jurnalistik terjadi dua pelanggaran: pertama, melanggar etika kehidupan pribadi atau privasi dan, kedua, mengabaikan perlindungan dalam pemberitaan pers bagi anak-anak yang masih di bawah umur, sebagaimana yang berlaku bagi pelaku tindak pidana yang belum berumur 16 tahun.
Di samping masuk ke ranah hukum, kasus video asusila ini juga berdampak pada hadirnya resiko traumatik yang kelak menjangkiti para pelaku dan keluarga pelaku. Hal ini ditandai pelaku yang masih berusia remaja telah mengalami kekerasan simbolik. Pierre Bourdieu (1970) mengartikan kekerasan simbolik adalah pemaksaan sistem simbolisme dan makna (misalnya kebudayaan) terhadap kelompok atau kelas tertentu hingga sedemikian rupa sehingga hal itu dialami sebagai sesuatu yang sah (Ibid, 157). Dengan demikian, penggambaran realitas melalui penggunaan bahasa dan gambar yang berpotensi melekatnya stereotipe negatif kepada remaja tersebut. Stereotipe negatif atau cap buruk berupa pelaku cabul dan penyebar video cabul selamanya akan disandang remaja tersebut. Selain itu, lingkungan sekolah juga terkena imbas stereotipe negatif tersebut. kenyataan inilah yang kemudian pengadaian sudah jatuh tertimpa tangga sedang terbukti

Tindakan kedua media massa online yang memublikasikan masalah privasi seolah-olah sebagai persoalan publik, sebenarnya mencerminkan alam pikiran (sebagian) masyarakat kita yang puritan. Sebab, ada kecenderungan media massa tersebut hanya bertugas "mereproduksi saja" ketidakmengertian masyarakat tentang perbedaan antara "ruang privat" dan "ruang komunal". Hal ini ditandai pemberitaan d mulai dari judul sampai hampir seluruh isinya seolah ikut bersorak-sorai dengan publik yang sama-sama tidak mempertimbangkan dan tidak memahami masalah privasi. 
"Suasana intim" dalam pemberitaan dapat timbul karena wartawan secara emosional terbawa oleh arus reaksi publik-dengan budaya yang tidak dapat memperlakukan peristiwa privat secara proporsional. Diantaranya pengungkapan identitas korban meskipun hanya ditunjukkan nama inisial namun alamat sekolah para pelaku tampak jelas sehingga berpeluang untuk mencari kebenaran identitas pelaku tersebut akan mudah diketahui oleh publik. Disinilah kemudian menjadi masalah ketika empati wartawan dipertanyakan seputar mengapa pengungkapan para pelaku penyebar dan atau pengedar video porno juga tidak banyak ditelusuri dan diulas bahkan ditampilkan fotonya sebagai bentuk pembelajaran soal sanksi hukum dan sosial sebagaimana pengungkapan rinci ciri-ciri pemeran video asusila.

Berdasarkan ilustrasi hasil analisis kasus bentuk-bentuk kekerasan simbolik media massa online terkait pemberitaan kasus video asusila pelajar di Kota Bogor tersebut, melalui penelitian ini mencoba memberikan saran kepada awak media diantaranya :

Pertama, wartawan dihimbau menjaga dan melindungi privasi narasumber terutama anak adalah upaya untuk menghormati pengalaman traumatis narasumber melalui teks berita, gambar, atau foto termasuk pertimbangan-pertimbangan untuk peliputan berita investigasi bagi kepentingan publik.

Kedua, wartawan dihimbau dapat menghindari memproduksi program dan publikasi gambar-gambar dan informasi yang dapat merusak anak -terutama dilakukan melalui media yang dikonsumsi khalayak umum termasuk anak. Selanjutnya wartawan juga dapat menghindari presentasi yang mengandung stereotip (stigmatisasi) dan sensasional dalam mempromosikan konten jurnalistik yang melibatkan anak.

Ketiga, wartawan dihimbau mempertimbangkan dengan hati-hati konsekuensi atas publikasi dari setiap konten jurnalistik yang melibatkan anak dan seyogyanya meminimalkan dampak buruk bagi anak. Hal yang penting dilakukan wartawan adalah memberikan hak dan akses bagi anak, di mana dirasakan perlu, untuk mengekspresikan pendapat mereka tanpa bujukan atau hal yang serupa.

Keempat, memastikan verifikasi independen atas informasi yang didapat dari anak dalam proses peliputan dan bersikap hati-hati dalam verifikasi agar tidak menempatkan anak yang menjadi sumber informasi dalam bahaya.

Kelima, wartawan dihimbau menghindari penggunaan gambar/visual bernuansa seksual dari anak.

\section{DAFTAR RUJUKAN}

Arifin, Anwar. (2003). Komunikasi Politik. Jakarta: Balai Pustaka.

Bungin, Burhan (2001), Erotika Media Massa, Surakarta : Muhammadiyah University Press.

(2004), dalam Jurnal Perempuan edisi Pornografi no. 38, Jakarta: Yayasan Jurnal Perempuan, Cet. I.November

Desmon Morris, (1977), manwatching: A Field Guide to Human Behaviour. New York: Harry N. Abrams, Inc. dalam Yasraf Amir Piliang, 2004, Posrealitas: Realitas Kebudayaan dalam Era Posmetafisika, Yogyakarta: Jalasutra. 
Fashri, Fauzi. (2007). "Penyingkapan Kuasa Simbol. Yogyakarta: Juxtapose.

Halliday, M.A.K. (1978), Language as Social Semiotic: The Social Interpretation of Language and Meaning. London: Edward Arnold. dalam Anang Santoso. 2008. Jejak Halliday dalam Linguistik Kritis dan Analisis Wacana Krttis. Jurnal Bahasa dan Seni, Tahun 36 Nomor 1 Februari 2008, Universitas

Negeri Malang: Jurusan Sastra Indonesia Fakultas Sastra.

https://kippas.wordpress.com/2007/06/04/ke

tika-jurnalisme-kehilangan-empati/ diakses Selasa 7 Juni 2016 pukul 13.00 WIB

Piliang, Yasraf Amir. Perempuan dan Mesin Hasrat Kapitalisme: Komodifikasi Perempuan dalam Program Hiburan Media Televisi, hal. 105 - 132. Dalam Siregar, Amir, Rondang Pasaribu, dan Ismay Prihastuti (eds.). Eksplorasi Gender di Ranah Jurnalisme dan Hiburan. Yogyakarta: Yayasan Galang, 2000.
(2004),

Posrealitas: Realitas Kebudayaan dalam Era Posmetafisika, Yogyakarta: Jalasutra.

Rusdiarti, S. R. (2003). "Bahasa, Pertarungan Simbolik, dan Kekuasaan.” Jurnal Basis, Edisi Khusus Pierre Bourdieu, No. 11-12 Tahun ke-52, November-Desember 2003.

Sudaryanto. (1993). Metode dan Aneka Teknik Analisis Bahasa. Yogyakarta: Duta Wacana University Press. 